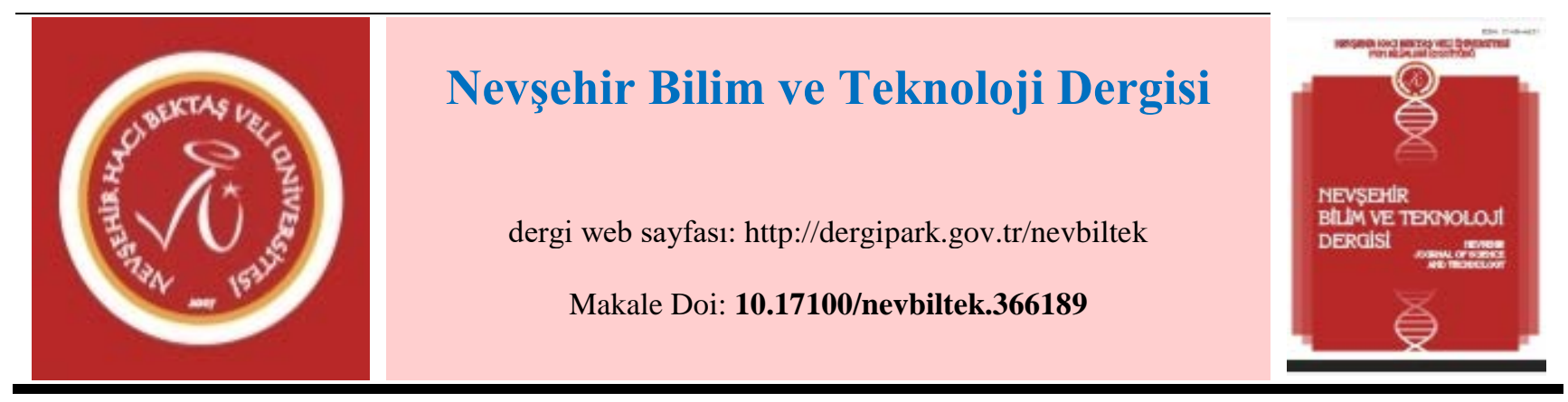

\title{
Baryum Karbonat İlavesinin Porselen Seramik Karoların Özelliklerine Etkisi 1
}

Hülya KAFTELEN ODABAŞI ${ }^{1}$, Ümit Engin ANIL ${ }^{2}$, Akın ODABAŞI ${ }^{3}$, Battal Kadir KOCABIYIK ${ }^{4}$

${ }^{1}$ Fırat Üniversitesi, Sivil Havacılık Yüksekokulu, Uçak-Gövde Motor Bölümü, Elazı̆̆

${ }^{2}$ Kaleseramik, Teknik Seramik Araştırma Merkezi, Çanakkale

${ }^{3}$ Fırat Üniversitesi, Mühendislik Fakültesi, Metalurji ve Malzeme Mühendisliği Bölümü, Elazlğ

${ }^{4}$ Karadeniz Teknik Üniversitesi, Mühendislik Fakültesi, Metalurji ve Malzeme Mühendisliği Bölümü, Trabzon

Öz

Bu çalışmada, 6 farklı ( ağırlıkça \%0, \%2-10 baryum karbonat içeren) porselen karo $1210{ }^{\circ} \mathrm{C}$ sıcaklıkta pişirilerek üretilmişlerdir. İkincil bir ergitici olarak baryum karbonatın seramiklerin lineer küçülme, yığınsal yoğunluk ve su emme özelliklerine etkileri incelenmiştir. Seramiklerin mikroyapı ve kimyasal analizleri, sırasıyla SEM ve XRD analizleri ile incelenmiştir. Baryum karbonatın seramiklere ağırlıkça \%2-6 ilavesi, porselen karolarda istenilen su emme değerinin (sıfir) etkilemediği görülmüştür. Bununla birlikte, ağıllıkça\% 8 ve ağırlıkça\% 10 baryum karbonat ilave edildikten sonra\% 6.65'e kadar çarpıcı bir şekilde arttı̆̆ı bulunmuştur.

Anahtar Kelimeler: Baryum karbonat, ergitici, porselen karo, feldispat

\section{Effect of Barium Carbonate Addition on the Properties of Porcelain Ceramic Tile}

\section{Abstract}

In this study, six different recipes ( $0 \%, 2-10$ wt. $\%$ with barium carbonate) of porcelain tile were fabricated using the firing temperature of $1210{ }^{\circ} \mathrm{C}$. The effects of barium carbonate as a secondary flux material on the linear shrinkage, bulk density and water absorption properties of ceramics were investigated. Microstructure and chemical analysis of ceramics were examined using SEM and XRD analysis instruments, respectively. Addition of barium carbonate between 2-6 wt.\% on the ceramics did not affect water absorption value (zero) which was recommended for porcelain tiles. However this was found to dramatically increase up to $6.65 \%$ after addition of $8 \mathrm{wt} . \%$ and $10 \mathrm{wt} . \%$ barium carbonate.

Keywords: Barium carbonate, flux, porcelain tile, feldspar

\footnotetext{
${ }^{1}$ Bu makalenin tamamı 11-13 Ekim 2017'de Kapadokya'da gerçekleştirilen "International Conference on Material Science and Technology in Cappadocia (IMSTEC’17)" konferansında sunulmuştur.

Sorumlu yazar e-mail: hkodabasi@firat.edu.tr
} 


\section{Introduction}

Porcelain tiles are obtained via sintering the pressed green body at $\sim 1200^{\circ} \mathrm{C}$ within a single fast-firing cycle [1]. They are typically composed of the mixture of clay, kaoline and feldspar. Among the raw materials, feldspar acts as a fluxing agent enhances glassy phase formation which promotes the mullite crystal growth and hence improves the firing process through filling interconnected pores. Such fluxes give rise to a viscous liquid phase, which plays an important role to obtain high densified ceramic bodies [2]. They improve the strength, toughness, and durability of the ceramic body [1].

The subject of numerous studies in the literature is generally based on the use of alternative materials such as clay materials [3], diopside [4], talc and albite as flux [5, 6] etc. to fabricate porcelain tile. However, the use of alternative flux materials which enhance the strength of porcelain bodies, are limited.

This work presents the investigation that undertaken the potential use of barium carbonate as secondary flux materials in porcelain tile. In this study, utilization of barium carbonate and the effects of their content on some technological properties including water absorption, linear firing shrinkage, and microstructure have been studied. Additionally, these properties are compared with an industrial porcelain ceramic tile.

\section{Material and Methods}

The chemical analysis of the starting raw materials used in this study is presented in Table 1 . The loss on ignition (L.O.I) indicates the relative proportion between plastic and non-plastic compounds in the clay and albite.

For this study, six different porcelain tile were prepared contaning different amount of barium carbonate as a secondary flux which partially replace by feldspar. The raw material contents (wt.\%) of six samples are shown in Table 2. For the base porcelain tile ceramics, kaolen and albite (soda feldspar) were used as the starting materials. Raw materials were supplied from Kalemaden Company, Turkey. 0.2 wt.\% sodium silicate was used as a deflocculant.

Table 1. The chemical analysis of raw materials (wt.\%).

\begin{tabular}{|c|c|c|c|c|c|c|c|c|c|}
\hline $\begin{array}{l}\text { Raw } \\
\text { Materials }\end{array}$ & $\mathrm{SiO}_{2}$ & $\mathrm{Al}_{2} \mathrm{O}_{3}$ & $\mathrm{TiO}_{2}$ & $\mathrm{Fe}_{2} \mathrm{O}_{3}$ & $\mathrm{CaO}$ & MgO & $\mathrm{Na}_{2} \mathrm{O}$ & $\mathbf{K}_{2} \mathbf{O}$ & L.O.I ${ }^{*}$ \\
\hline Clay 1 & 59.23 & 26.08 & 1.45 & 2.38 & 0.31 & 0.43 & 0.36 & 1.97 & 7.64 \\
\hline Clay 2 & 57.73 & 28.22 & 1.38 & 1.22 & 0.32 & 0.49 & 0.37 & 2.11 & 7.99 \\
\hline Kaolin 1 & 68.98 & 21.77 & 0.40 & 0.16 & 0.21 & 0.03 & 0.04 & 0.25 & 8.11 \\
\hline Kaolin 2 & 67.03 & 23.12 & 0.43 & 0.40 & 0.10 & 0.01 & 0.03 & 0.10 & 8.39 \\
\hline Albite & 70.96 & 17.87 & 0.32 & 0.05 & 0.60 & 0.17 & 9.50 & 0.24 & 0.29 \\
\hline
\end{tabular}

Table 2. Studied porcelain ceramics (weight basis).

\begin{tabular}{lllll}
\hline $\begin{array}{l}\text { Sample } \\
\text { name }\end{array}$ & Clay & Kaolen & Feldspar & $\begin{array}{l}\mathrm{BaCO}_{3} \\
\text { (wt.\%) }\end{array}$ \\
Base & 23 & 27 & 50 & - \\
B2 & 23 & 27 & 48 & 2 \\
B4 & 23 & 27 & 46 & 4 \\
B6 & 23 & 27 & 44 & 6 \\
B8 & 23 & 27 & 42 & 8 \\
B10 & 23 & 27 & 40 & 10 \\
\hline
\end{tabular}

The raw materials were mixed for 20 min using a planetary ball mill (Gabbrielli ${ }^{\mathrm{TM}}$ ) with alumina balls. The slurry was dried at $100^{\circ} \mathrm{C}$ in an oven until $6 \%$ of humidity. Powder mixtures were uniaxially pressed into cylindrical 
specimens with a dimension of $\Phi 45 \mathrm{~mm} \times 5 \mathrm{~mm}$ under a pressure of $44.8 \mathrm{~kg} / \mathrm{cm}^{2}$. The specimens were dried at $70^{\circ} \mathrm{C}$ for $24 \mathrm{~h}$ and then fired at $1210^{\circ} \mathrm{C}$ for $2 \mathrm{~h}$. Fired samples were used to determine the linear shrinkage, water absorption (Archimedes' water displacement method) and bulk density using determined by the Archimedes method using distilled water as liquid media. The results presented are the average of those obtained for at least five samples.

The DSC/TGA (Leinseis ${ }^{\mathrm{TM}}$ ) analysis of powder mixtures were carried out under air at temperatures up to $1200^{\circ} \mathrm{C}$ with $10^{\circ} \mathrm{C} \mathrm{min}^{-1}$ heating rate. The type of crystalline phases of the fired samples were identified from XRD

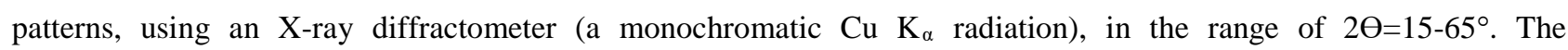
microstructure of the fired samples was examined by SEM (Zeiss Evo ${ }^{\mathrm{TM}}$ ).

\section{Results}

Linear shrinkage, water absorption and bulk density of fired samples are given in Table 3.

\begin{tabular}{cccc}
\multicolumn{4}{c}{ Table 3. Characterization results of the fired samples. } \\
\hline $\begin{array}{c}\text { Sample } \\
\text { name }\end{array}$ & $\begin{array}{c}\text { Linear } \\
\text { shrinkage } \\
\mathbf{( \% )}\end{array}$ & $\begin{array}{c}\text { Water } \\
\text { absorp. } \\
\text { (\%) }\end{array}$ & $\begin{array}{c}\text { Bulk } \\
\text { density } \\
\text { (g/cm }\end{array}$ \\
Base & 6.93 & 0 & 2.43 \\
B2 & 4.25 & 0 & 2.42 \\
B4 & 5.61 & 0 & 2.34 \\
B6 & 5.72 & 0 & 2.39 \\
B8 & 3.86 & 3.4 & 2.26 \\
B10 & 1.91 & 6.65 & 2.14 \\
\hline
\end{tabular}

The linear shrinkage value of the samples containing 8 wt.\% and $10 \mathrm{wt} . \% \mathrm{BaCO}_{3}$ significantly was reduced compared with base porcelain tile ceramic. This result indicate that after 6 wt.\% barium carbonate addition caused an overfiring effect [7] in samples B8 and B10 since the barium carbonate are more powerful flux than feldpar. Note that the linear shrinkage value of B2 sample is lower than B4 sample. This may be due to

Water absorption percentage of porcelain tile ceramics was measured as zero, which is desirable for porcelain tiles, up to 6 wt.\% barium carbonate addition after 8 wt.\% barium carbonate addition water absorption (\%) values dramatically increases. This value reaches $6.65 \%$ for 10 wt.\% barium carbonate containing ceramic. This indicates that addition of barium carbonate up to $6 \mathrm{wt}$ \% is acceptable as flux material for production of porcelain tiles. While base sample shows the highest bulk density value of $2.43 \mathrm{~g} / \mathrm{cm}^{3}$, the lowest bulk density value was obtained in B10 sample containing 10 wt.\% barium carbonate with maximum water absorption value. The density values of samples vary between 2.14-2.43 g/ $\mathrm{cm}^{3}$. Additionally, the appearant porosity was recorded \%3 and \%8 for samples B8 and B10 respectively. This contributes to increase in the water absorption after 8 wt.\% $\mathrm{BaCO}_{3}$ addition.

Thermal behavior during the firing of ceramic mixtures containing different amount of barium carbonate was examined by DSC to obtain useful information on the evoltion of solid-state reactions/or phase transitions of the samples during firing process. Figure 1 gives DSC curves in a temperature range $20-1200{ }^{\circ} \mathrm{C}$ from ceramic mixtures in an air. All DSC curves display two endothermic peaks at $104{ }^{\circ} \mathrm{C}$ and $560{ }^{\circ} \mathrm{C}$ and one exothermic peak at $1000^{\circ} \mathrm{C}$. The first endothermic peak corresponds to the water evaporation of the clay. The second peak corresponds to the kaolinite decomposition. The exothermic peak at around $1000{ }^{\circ} \mathrm{C}$ is attributed to formation of mullite crystal phase, also 
observed in XRD analysis of fired ceramic (Figure 2). Additionally, a weak exothermic peak at around $810{ }^{\circ} \mathrm{C}$ in curves of $\mathrm{B} 8$ and $\mathrm{B} 10$ is probably due to the decomposition of $\mathrm{BaCO}_{3}[8]$.

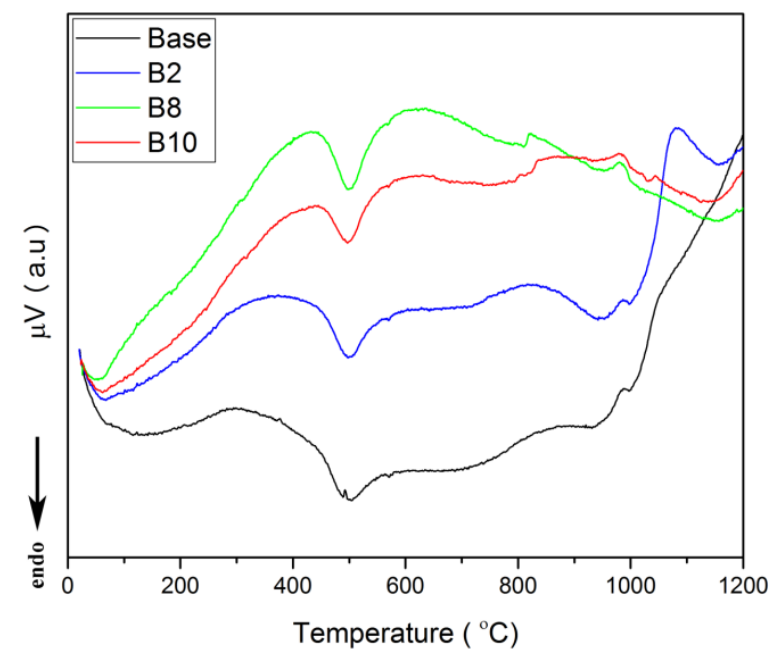

Figure 1. DSC curves of mixed ceramic powders.

Fig. 2 gives the XRD patterns of base and B10 porcelain ceramic samples fired at $1210{ }^{\circ} \mathrm{C}$. The main phases are quartz (JCPDS card no. 5-490), mullite (JCPDS card no. 15-776) and glassy phase is also present in both base and 10 wt.\% $\mathrm{BaCO}_{3}$ containing samples. The rietveld results show that $28 \%$ quartz, $17 \%$ mullite, 53 \% glassy phase were formed in base ceramic material heated at $1210^{\circ} \mathrm{C}$. The background in the fired bodies XRD patterns is observed to be quite high indicating the presence of glassy phase. Literature survey shows that mullite crystal phase and the residual quartz are generally formed in clay bodies when the firing was performed at the temperatures above $1150{ }^{\circ} \mathrm{C}$ [9].

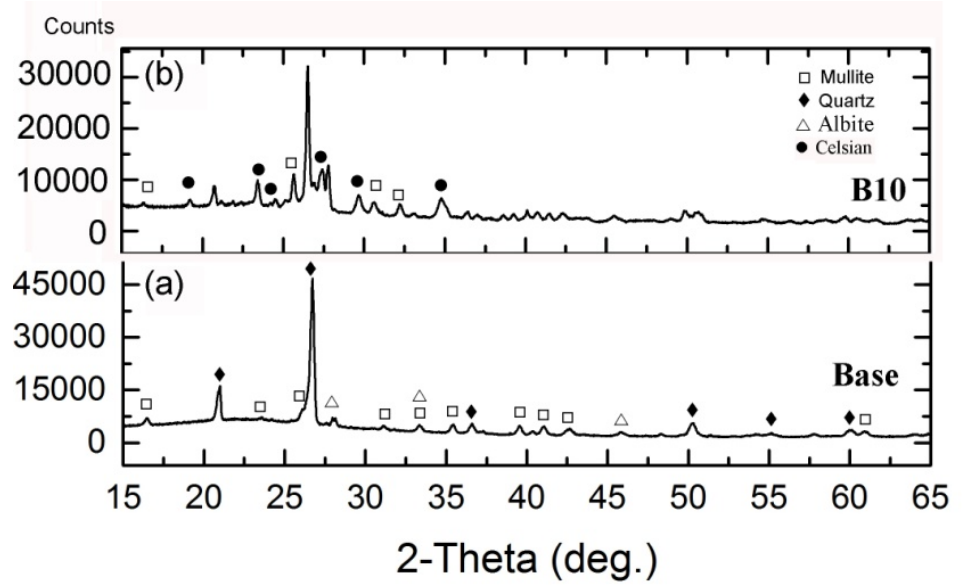

Figure 2. XRD analysis of (a) base, (b) B10 porcelain sample.

Additionally, XRD analysis results show that celsian phase (monoclinic, JPDS card no. 281284) is formed in B10 samples. Note that the XRD analysis of B8 is similar with the B10 therefore we only give the result for B10 sample. Furthermore, the peak intensities of mullite and quartz phase decreased in the XRD analysis of B10 sample compared with the base one. 
Presence of mullite phase is also confirmed by SEM images (Figure 4) taken from polished and etched (with HF) surface of fired ceramics.
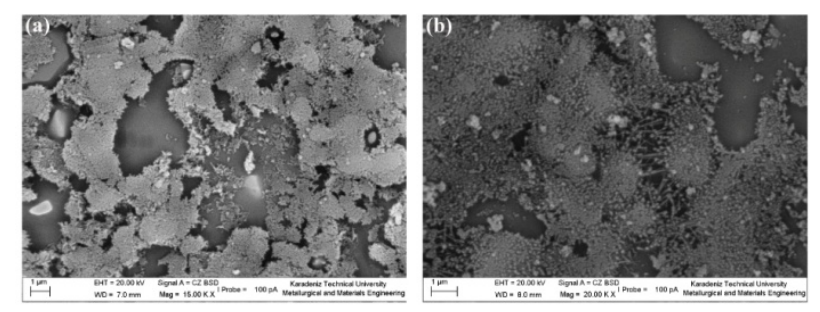

Figure 3. SEM images of (a) base and (b) B6 ceramic samples.

Figure 3 shows microstructures of fired the base and B6 porcelain ceramics. Etching with 3\% HF solution revealed mostly scaly crystals of mullite and quartz particles in SEM image of base porcelain sample. However, the morphology of mullite crystals are needle-like shaped (secondary mullite) in B6 sample. This indicates that the presence of $\mathrm{BaCO}_{3}$ contributes the growth of mullite crystal due to its flux character. In addition, large quartz crystals surrounded by mullite crystals were observed in Fig. 3 (a) and Fig. 3(b).

Figure 4 gives the high magnification SEM image of B10 sample. Different from Figure 3b, needle-like mullite crystals were not observed in the microstructure of B10 sample. This revealed that both mullite (M) and quartz (Q) phase are present together as dissolved phase in the glassy phase (Fig. 4).

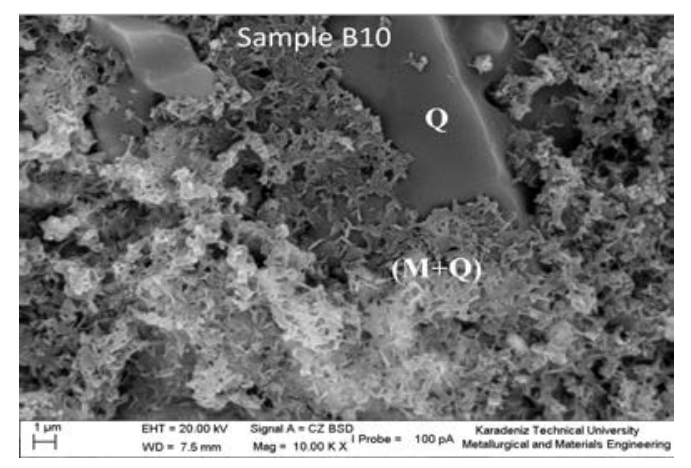

Figure 4. High magnification SEM micrograph of B10 sample. 

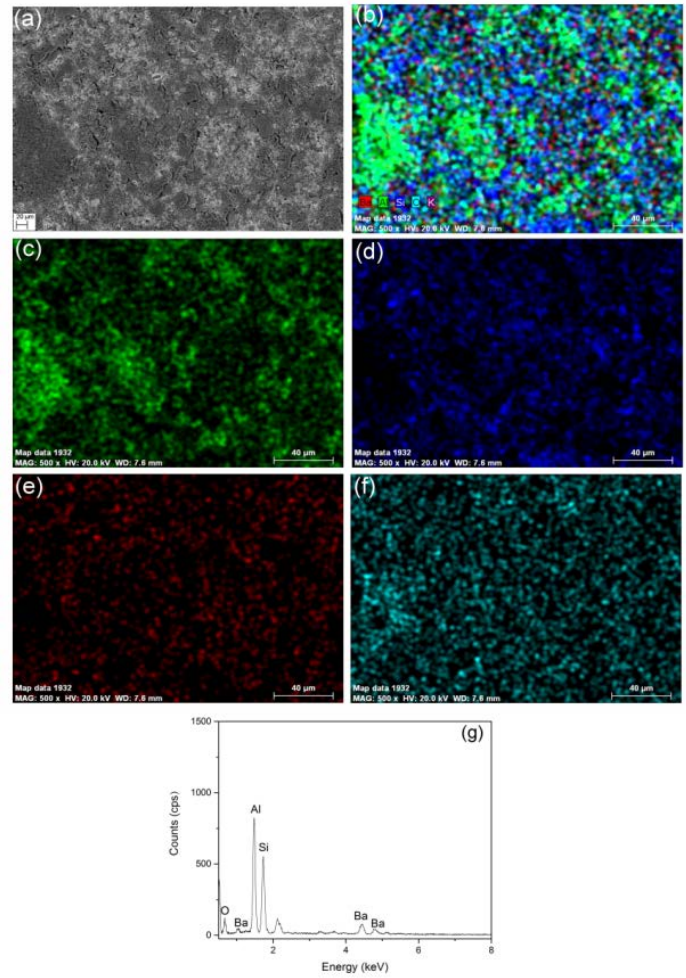

Figure 5. (a) SEM image of B10 ceramic sample (b) element distribution map showing the pixels indexed as $\mathrm{Ba}$ (red), $\mathrm{Al}$ (green), $\mathrm{Si}$ (blue) and O (magenta), separated elemental distribution maps for $\mathrm{Al}$ (c), Si (d), Ba (e), O (f) and corresponding EDX analysis (g).

Energy-dispersive X-ray (EDX) spectroscopic maps provide useful information on the distribution of elements within the overall microstructure. To observe Ba distribution in the sintered porcelain tiles, the B10 sample containing 10 wt.\% barium carbonate has been examined, see Fig. 5. The full area of the SEM image depicted in Fig. 5(a) was investigated for distributions of $\mathrm{Al}, \mathrm{Si}, \mathrm{Ba}$ and $\mathrm{O}$, see Fig. 5(c-f), a superimposed phase distribution map is shown in Fig. 5(b). Elemental EDX mapping data for Ba indicates that barium is uniformly distributed in ceramic structure. The EDX spectra corresponding to the area in Fig. 5(a) are given in Fig. 5(g). Note that the signal about $2 \mathrm{keV}$ belongs to coating materials, $\mathrm{Au}$.

\section{Conclusion}

In this study, the effect of the substitution of barium carbonate (2-10 wt.\%) with feldspar in different amount on the physical properties and microstructure of porcelain ceramics were investigated. According to the results, the following conclusions can be drawn:

$\mathrm{XRD}$ analysis showed that quartz and mullite as major phases and a glassy phase was also present in porcelain tile structure. Formation of a new barium aluminum silicate phase was observed in the XRD analysis of $8 \%$ and 10 wt.\% $\mathrm{BaCO}_{3}$ containing samples.

The linear shrinkage value of the samples containing different amount of barium carbonate decreased compared with base porcelain tile. This significant effect was observed when the $\mathrm{BaCO}_{3}$ weight percentage was reached 8 and 10 wt.\%.

SEM images showed that (quartz + mullite) in glassy phase formation appears in B10 sample and low feldspar content in B10 sample led to low firing shrinkage. 
In a general analysis, the experimental fired bodies presented similar characteristics, as well as similar properties (up to 6 wt.\% $\mathrm{BaCO}_{3}$ addition) and microstructure to an industrial base ceramic fabricated in Kaleseramik /Turkey. Hence the results shows that addition of barium carbonate between 2-6 wt.\% to porcelain tile is acceptable as secondary flux materials.

\section{Acknowledgment}

The authors thank for support of the Kaleseramik Technical Ceramic R\&D Center.

\section{References}

[1] Sanchez E., Ibanez M.J., Garcia-Ten J., Quereda M.F., Hutchings I.M., Xu Y.M., "Porcelain tile microstructure: implications for polished tile properties” Journal of European Ceramic Society, 26, 2533$2540,2006$.

[2] Jorge M., Jesús R., Maximina R., "Mullite development on firing in porcelain stoneware bodies” Journal of European Ceramic Society, 30, 1599-1607, 2010.

[3] Vieira C.M.F., Peçanha L.A., Monteiro S.N., "Effect of kaolinitic clays from the State of Rio de Janeiro in the composition of whiteware floor tile bodies” Cerâmica, 52, 138-145, 2006.

[4] Wu J., Li K., Xu X., Zhang Y., Xu, X., Lao X., “White porcelain material based on diopside” International Journal of Applied Ceramic Technology, 14, 454-460, 2017.

[5] Khalil N.M., Wahsh M.M.S., Gaber A., "The effect of albite additions on the sintering, phase compositions and microstructure of vitreous ceramic tiles” Journal of Ceramic Processing Research, 17, 478-484, 2016.

[6] Bayer Ozturk Z., Ay N. “An investigation of the effect of alkaline oxides on porcelain tiles using factorial design”, Journal of Ceramic Processing Research, 13, No. 5, 635-640, 2012.

[7] Serra M.F., Conconi M.S., Suarez G., Aglietti E.F., Rendtroff N.M., "Volcanic ash as flux in clay based triaxial ceramic materials, effect of the firing temperature in phases and mechanical properties" Ceramics International, 41(5), 6169-6177, 2015.

[8] Vela E., Peiteado M., Garcia F. Caballero A.C., Fernandez J.F. "Sintering behavior of steatite materials with barium carbonate flux" Ceramics International 33 (2007) 1325-1329.

[9] Mukhopadhyay T.K., Das M., Ghosh S., Chakrabarti S., Ghatak S., "Microstructure and thermomechanical properties of a talc doped stoneware composition containing illitic clay” Ceramics International, 29, 587-597, 2003. 


\section{Uzun Özet}

\section{Giriş}

Porselen karolar, yaklaşık $1200{ }^{\circ} \mathrm{C}$ sıcaklıklarda şekillendirilmiş yaş bünyenin hızlı pişirme yöntemi ile elde edilen ve seramik karolarla karşılaştırıldığında yüksek mukavemet, düşük su emme $(\leq 0.5 \%)$, lekelenme ve donmaya karşı dirençli malzemelerdir. Yüksek mukavemet, donma ve lekeye karşı dirençleri sebebiyle yaya trafiğinin yoğun olduğu alışveriş merkezleri, havaalanları gibi yerlerde kullanılırlar. Seramik karolara göre daha ince ve saf kil, kaolen ve feldispat malzemelerinin belirli kompozisyonlarda karıştırılmasından elde edilirler. Bu malzemeler arasında feldispat, pişirme prosesi sırasında camsı faz oluşumuna neden olur ve camsı faz mikroyapıda boşlukları düşük su emme dolayısıyla donmaya karşı direnç özelliklerini arttırmaktadır. Literatürde porselen bünyelerde ergitici (flux) olarak kullanılan feldispat yerine alternatif olarak, diopsit, talc, kil minerali gibi malzemeler kullanılarak çalışmalar yapılmıştır. Ancak alternatif ergitici malzemeler üzerine sınırlı sayıda çalışmalar mevcuttur. Bu çalışmada daha önce porselen bünyelerde uygulanmamış olan yüksek ergitici özelliğine sahip baryum karbonat malzemesinin porselen bünyelerin özelliklerine etkisi incelenmiştir. $\mathrm{Bu}$ çalışmada, ağırlıkça \%2-10 aralığında baryum karbonat $\left(\mathrm{BaCO}_{3}\right)$ seramik porselen karolara ikincil ergitici malzeme olarak ilave edilmiş ve karolar $1210{ }^{\circ} \mathrm{C}$ sıcaklıkta pişirilerek üretilmişlerdir. Farklı oranlarda ilave edilen baryum karbonatın seramiklerin lineer küçülme, yığınsal yoğunluk ve su emme, kimyasal ve mikroyapı özelliklerine etkileri incelenmiştir ve bu özellikler endüstriyel olarak Kale Seramik bünyesinde üretilen porselen karoların özellikleri ile karşılaştırılmıştır. Ayrıca, porselen karo tozları pişirme prosesi öncesi, pişirme süresince görülebilecek katı-hal reaksiyonları ve/veya faz transformasyonları termal (DSC) analizi ile incelenmiştir. Pişirme sonrası porselen karoların mikroyapı ve faz analizleri sırasıyla SEM ve XRD analizleri ile incelenmiştir.

\section{Deneysel Çalışmalar}

$\mathrm{Bu}$ çalışmada, porselen bünyelerde feldispat ile yer değiştirecek şekilde ikincil ergitici malzemesi olarak ağırlıkça \%0$10 \mathrm{BaCO}_{3}$ ilavesi yapılmıştır. standart porselen numuneler yaklaşık olarak \%50 feldispat, \%23 kil ve \%27 kaolen'den oluşmaktadır. Litre ağırlığı $177 \mathrm{~g} /$ lt olacak bilyalı değirmen kullanılarak şekilde çamur hazırlanmıştır. Hazırlanan çamur kurutulup nem (\% 6) veriledikten sonra $\Phi 45 \mathrm{~mm} \times 5 \mathrm{~mm}$ boyutlarında disk şeklinde numuneler preslenerek elde edilmiştir. Kurutulmuş çamurdan alınan tozlara pişme öncesi termal analiz uygulanmış ve sinterleme esnasında oluşabilecek reaksiyonlar tespit edilmiştir. Numuneler $\sim 1200{ }^{\circ} \mathrm{C}$ 'de pişirme işlemine tabi tutulmuşlardır. Pişmiş numunelerin lineer küçülme su emme, yığın yoğunluk gibi fiziksel özellikleri standartlara uygun şekilde belirlenmişstir. Yoğunluk değerleri her kompozisyon için en az 3 farklı numune için hassas terazi ve Arşimet yoğunluk kitinden oluşan deney düzeneği kullanılarak hesaplanmıştır. Numuneler, pişme işlemi sonrası kesilerek parlatılmıştır ve ve \%3 'lük HF çözeltisi ile $2 \mathrm{dk}$ boyunca dağlanmıştır. Mikroyapı özellikleri taramalı elektron mikroskobu (SEM, Zeiss Evo) kullanılarak incelenmiştir. X-ışını kırınımı cihazı kullanılarak numunelerin pişme sonrası faz analizleri ve Rietveld methodu ile olası fazların miktarları tespit edilmiştir.

\section{Sonuçlar ve Tartışma}

Pişirme esnasında oluşabilecek reaksiyonları gözlemek amacıyla, seramik porselen tozların bütün kompozisyonları için 20-1200 ${ }^{\circ} \mathrm{C}$ aralığında yapılan termal analiz (DSC) alınmıştır. DSC analizlerinde, kil minerali içerisindeki suyun buharlaşması ve kaolenin dekompozisyonu sırasıyla $104{ }^{\circ} \mathrm{C}$ ve $560{ }^{\circ} \mathrm{C}$ sıcaklıklarında endotermik piklere ve müllit kristalinin oluşması da yaklaşık $1000^{\circ} \mathrm{C}$ 'de ise bir ekzotermik pikin görülmesine neden olmuştur. Ayrıca $\% 8$ ve $\% 10$ $\mathrm{BaCO}_{3}$ içeren numune tozlarından alınan DSC analizlerinde yaklaşık $810{ }^{\circ} \mathrm{C}$ 'de baryum karbonatın bozunması sonucu oluştuğu görülmektedir. Pişmiş porselen numunelerin faz analizleri (XRD) sonucunda müllit, kuvars ve camsı fazların ana fazlar olduğu ve ayrıca $\% 8$ ve $\% 10 \mathrm{BaCO}_{3}$ ilaveli numunelerde selsian fazının da oluştuğu görülmektedir. $\mathrm{BaCO}_{3}$ ilavesiz referans numunesinin $1210^{\circ} \mathrm{C}$ 'de pişirme sonucunda $\% 28$ kuvars, \%17 müllit ve \%53 camsı fazdan oluştuğu Rietveld analizi sonucunda hesaplanmıştır. Numunelerin mikroyapı incelemelerinde, referans numunede $\left(\mathrm{BaCO}_{3}\right.$ ilavesiz) görülen müllit kristalleri morfolojisi $\mathrm{BaCO}_{3}$ ilavesi ile iğnemsi yapıya dönüştüğü görülmektedir. Baryum karbonatın seramiklere ağırlıkça \%2-6 ilavesi, porselen karolarda istenilen su emme değerinin (sıfır) etkilemediği görülmüştür. Bununla birlikte, ağırlıkça\% 8 ve ağırlıkça\% 10 baryum karbonat ilave edildikten sonra\% 6.65 'e kadar çarpıcı bir şekilde arttığı bulunmuştur. Sonuç olarak Kaleseramik'de endüstriyel olarak üretilen porselen seramik karoların özelliklerine yakın özellikler \%2, \%4 $\mathrm{BaCO}_{3}$ ilaveli porselenlerde görülmüştür o nedenle ağırlıça \%6 'ya kadar ikincil ergitici malzeme olarak $\mathrm{BaCO}_{3}$ ilavesi yapılabilir. 